\title{
Exploring Beliefs and Practices among Teachers to Elevate Creativity Level of Preschool
} Children

\author{
Azli Ariffin \\ Sultan Idris Education University \\ azli@fppm.upsi.edu.my \\ Roselan Baki \\ University Putra Malaysia \\ drbroselan@gmail.com
}

DOI:10.5901/mjss.2014.v5n22p457

\begin{abstract}
The purpose of this study is to examine the influence of teacher's beliefs on creativity construction practices of preschool children in class, explore and understand the beliefs of preschool teachers on the concept of creativity, observe actual practices of preschool teachers in the classroom and identify the factors that may influence teachers' practices in the classroom. This exploratory study adopted the use of qualitative method of inquiry to provide an in-depth understanding of the area being investigated. Interview and observation of four preschool teachers were purposively selected from two government schools were used to collected data. Findings revealed that all the teachers in this study expressed their views that creativity is something related to art works. The teachers' beliefs about how best to facilitate children's creativity can be divided into three categories; (a) Teaching methods, (b) Classroom environment and (c) Characteristic of the teachers. The findings also reveal varieties of constraining factors which influence teachers' classroom practices in promoting creativity for the preschool children. The implication of the findings are that further research need to conduct to identify the value in promoting creativity for children through an effective approach.
\end{abstract}

Keywords: Beliefs, practice, preschool.

\section{Introduction}

Creativity can be considered as one of the very complex, mysterious and enticing human behaviour. Every great invention or discovery, including all forms of artistic expression depends on high level of creative thinking. However, before the mid-1950s, creativity does not attract much attention among scholars or intellectuals during that time. From 121,000 list of articles appearing in the Psychological Abstracts (Smith, 1959, in Ruggiero 2004) between 1936 and 1959, there were only 186 specific articles that were related to creativity (Ruggiero, 2004).

Our daily lives are constantly surrounded with various problems that require us to think in finding the best solution. Whether we realize it or not, in our struggle to think for problem saving, creativity plays an important role in helping us to find ways that are innovative and effective. Since creativity can be defined as creating a new idea or concept (Guilford, 1950 Mindham, 2005), divergent thoughts (Butcher \& Nice, 2005), innovative (Butcher \& Nice, 2005), and seeing things in a new light (Mindham, 2005), it clearly demonstrates that creativity is the key to many things related to daily life.

Diakidoy \& Kanari (1991) stressed that every effort to improve the level of creativity in schools, should take into account individual factors by referring to teachers who will realize each objectives contained in the program and the national education curriculum. Stipek et al. (2001) mentioned that teachers uphold something that is reliable, this fact will shape teaching practices in the classroom. Pajares (1992) and Hofer et al. (1997) stated that teacher's beliefs can influence the perception and evaluation on the results of teaching, in addition to the choice of methods and activities. The ministry pays much attention to the development of children's creativity, hence studies that examine the understanding and trust of the teachers on the concept of creativity and the actual practice in the classroom need to be carried out, especially on the broad concept of creativity and multiple meanings, and definition.

Kupari (2003) stated that teacher's beliefs are a critical element in determining teaching and learning process in the classroom. According to Cooney and Lin (2001), every action taken by the teacher in the classroom is the result of the 
teacher's beliefs. With particular emphasis on aspects of teacher's beliefs, then hopefully it will help the teacher to be able to transform their way of teaching in educating the children, especially on the creativity aspect. This is because the study of teachers' beliefs and practices of teachers in class will contribute as basic knowledge that can be used for us to understand and develop a more effective teaching practices in the future (Kang \& Wallace, 2005; Levit, 2001 ; Luft, 1999; Tsai 2002).

Previous studies found that teacher's characters can influence (Pianta et al., 2005; Saracho \& Spodek, 2007; Mashburn et al., 2008), trust (Cassidy et al., 1995; Chang, 2003), and quality of early childhood programs (Burchinal et al., 2000, Bryant et al., 1994; Pianta et al., 2005; Howard-Jones, Taylor, \& Suton 2002; Peisner-Burchinal et al., 2001) on the social, emotional and cognitive development. However, there are very few studies that examine its influence on creativity, especially in the early ages of children.

In Malaysia, the importance of development of creative power in early childhood education is clearly stated in discourse of pre-school education curriculum. Among the six components found in the discourse is the creativity and aesthetics component with a focus on developing creative and expressive character through imagination and thinking (Ministry of Education Malaysia, 2001). In 2008, the National Pre-School Curriculum Standard (NPCS) was enacted to strengthen the existing curriculum. The goal is to develop the potential of children aged four to six years in a comprehensive and integrated approach to the physical, emotional, spiritual, intellectual and social development through a safe learning environment, nourished through activities that are fun, creative and meaningful (Ministry of Education, 2009) to provide children with basic skills and concepts to prepare them for learning at primary schools in the future. According to Grouws (2006), many studies have been conducted to see the relationship between belief and teaching practice. Therefore this kind of research is highly relevant to be carried out to explore the beliefs and practices of the teachers.

The purpose of this study is to examine the influence of teacher's beliefs on creativity construction practices of preschool children in class. The main objective is to:

(a) Explore and understand the beliefs of preschool teachers on the concept of creativity. (b)Observe actual practices of preschool teachers in the classroom.

(c) Identify the factors that may influence teachers' practices in the classroom.

This study provides an avenue for discussions among preschool teachers through its articulation of implications for teacher education and continuing professional development and may indicate cultural differences in the concept of creativity. Furthermore, this study will also provide a basis for judging whether current practice meets the requirement to promote children's creativity. The findings from this study also will be able to determine how teachers conceptualize creativity and what impact their concepts have on their interpretation and objectives more clearly both in curriculum requirements and in professional preparation and training.

\section{Method \\ Research design}

In order to obtain a deeper understanding of teachers' conceptions of creativity and their beliefs about the best way in promoting creativity in classroom this exploratory study adopted the use of qualitative method of inquiry to provide an indepth understanding of the area being investigated. The use of the qualitative method of inquiry is appropriate for this study because it is an attempt to understand the phenomenon of interest from the participant's perspective, not the researcher's. A qualitative researcher is interested in understanding the meaning people have constructed; that is how they make sense of their world and the experiences they have in the world (Sherman \& Webb, 1988). Moreover, Burn (1997) asserts that the task of the qualitative methodologist is to capture what people say and do as a product of how they interpret the complexity of their world, to understand events from the viewpoints of the participants.

\section{Sampling}

The subjects of this study consisted of four preschool teachers were purposively selected from two government schools. As Denzin and Lincoln (1994) put it, many qualitative researchers employ purposive, and not random, sampling methods. In the context of this study, the said teachers have been purposely selected for the fact that they might show differences in ideas, beliefs and practices because of the different characteristic of their personalities and physical settings. 


\section{Data Collection Methods}

Data were gathered using semi-structured interviews consisting of open-ended questions and classroom observations. The use of two instruments acts as a data triangulation to increase the authenticity and trustworthiness of the data collected. The data gathered from the interviews and observations were shared with the teachers and discussions were held with them to find out why they had acted in certain ways during their actual teaching. Data collections was done in three phases as two different schools with different settings were involved in this research. Classroom observation was thought to be the most appropriate means of obtaining information to answer the main questions of the link between teachers' perceptions of creativity and their actual practice in the classroom. The researcher employed non-participation observation technique where he observed the subjects without being actively involved with the activities which left him free to make notes and audio-recording.

\section{Findings}

In this study, the analyses provide three broad conceptual themes in attempt to address the research questions. The themes are:

1. Teachers' conceptions about creativity.

2. Preschool curricula that could promote children's creative development.

3. Teachers' priorities for creativity in the preschool curriculum.

4. The role of classroom environment in facilitating creativity.

\section{Teachers' conceptions about creativity}

All the teachers in this study expressed their views that creativity is something related to art works.

"Creativity is something involved with art like pasting small piece of paper on drawing blocks...I meant collage. It is something to do with drawing... other art activities such as colouring, painting or creating something from the clay".

Another teacher expressed her idea of creativity as a way to express feeling. Meanwhile, two teachers conceptualized creativity as the ability to produce something unique or something that is different and unexpected.

"When children can draw something that is unexpected and they can colour it beautifully and we can see varieties of object in their drawing such as tree, animals and another that is beyond our expectation". Teachers also considered creativity when children can draw nicely and with perfection. "When the children can draw a nice picture... for example if he can draw a ball then colour it very nicely and neatly".

\section{Preschool teachers act in the classroom}

Having analyzed the responses in the interview, the teachers' beliefs about how best to facilitate children's creativity can be divided into three categories; (a) Teaching methods, (b) Classroom environment and (c) Characteristic of the teachers.

(a) Teaching methods

All teachers believe that providing enough time for children to engage in arts activities will help to promote children's creativity. Besides that, giving children freedom is another way to facilitate children's creativity. Allowing some choices of their own in learning activities such as the freedom to use of materials and to sing any song are some examples given by some of the teachers.

"Give them freedom...for example they can use any colour as they like for their drawing".

The use of materials in the teaching and learning process is very important to facilitate children's creative development. This was expressed by all four teachers.

"Teaching materials are very important if we want to develop children creativity". 
Besides that, the teachers also expressed the need for the teacher to be flexible during teaching as they believed that doing so will help to promote children's creativity in the classroom. Three of the teachers was implied that by giving children the opportunity for interaction between themselves, and asking open-ended questions would also help to develop children's creativity. The teachers also responses that giving the opportunity for children to engage in group work and discussion is another way to promote creativity in the classroom.

\section{(b) Classroom environment}

Facilitating creativity in the classroom requires some commitment to space which

Means being aware of physical space in the classroom and of the ways it may foster children's creativity. All of the teachers believed that classroom environment plays an important role in promoting children's creativity. A classroom that is attractive and well-organized with learning corners can contribute towards children's creative development.

"Making the classroom look attractive is also important. Children like a classroom that is colourfull, attractive, some cartoon, toys like dolls, and things like this can make the children like the classroom and make them more creative".

Meanwhile, two other teachers said that plenty of resources in the classroom are also required not only for learning purpose but children to easily access materials including books, construction blocks and others.

\section{(c) Teachers' characteristics}

All teachers also agreed that teachers' personal qualities that they bring into the classroom are also important in nurturing children's creativity. A majority of the of the teachers mentioned that the promotion of children's creativity requires the teachers themselves to be creative. It was discovered that none of the teachers regard themselves as particularly creative and they are not confident about their teaching quality in promoting children's creativity. The statements below clearly illustrate about teachers' feeling about themselves: methods".

"I am not a creative teacher... I don't think that I am creative and I am not good at new teaching

"No, I am not creative. It is not easy to be creative teachers and I don't even know wheather I have developed children creativity so far."

In order to be creative, the teacher should be a hardworking person in implementing creative teaching and to prepare various creative activities. Hardworking is also one of the teachers' characteristic that the teacher should have to promote creativity in the classroom.

"You need to squeeze you head and think hard to look for new activities and thinking appropriate teaching materials to be included in the activities."

Another characteristic that teachers should have is confidence. This was expressed by two teachers.

"Teachers must be very confident intheir teaching and they must be ready to face any possibilities from the activities that they have planned. Not everythings you plan can be achieved and this applies to creative activities too."

Another important characteristic required to promote creativity in the classroom is that teacher has to be friendly. The term 'Friendly' in this context means that teachers have to be approachable to the children. Teachers should not be very strict so that children will feel free to be active in the learning activities in providing ideas and to participate without fear of making mistakes. Tolerance is another characteristic that a teacher should have to produce stimulating learning process towards the development of children's creativity. To be accepting of children's ideas; to be appreciative of any outcomes or products produced by the children and to be patient are among the criteria that the teacher should also have to produce creative children. 


\section{Constraining factors in promoting children's creativity}

In seeking to be creative teaching, teachers may often have to deal with what may seem to be rather unsupportive situations, and a number of social constraints. The findings reveal varieties of constraining factors which influence teachers' classroom practices in promoting creativity for the preschool children below:

\section{(a) Teachers' own pedagogical limitations}

Based on the responses from the interviews, most of the teachers felt that they don't know exactly how to implement teaching which specifically promotes children's creativity. Although all of them are trained teachers, they still found it very difficult to implement in the real classroom. All the teachers expressed their concern about their lack of knowledge in implementing integrated teaching and knowledge in mew methods of teaching, especially in math's, reading, writing, courteous behavior, health and safety and play and movement and also how to implement child-centered activities geared toward the promotion of creativity.

"It hard to implement creativity in other subjects especially in basic counting...even reading activities. It is easy to say but hard for me to do it and I don't know how to implement creative activity in my teaching."

\section{(b) Large class size}

Difficulty in managing the children in the classroom because of large class sizes in the classroom hinders teachers from carrying various learning activities in their teaching. The problem of class sizes had all the teachers expressing difficulty to concentrate in promoting children's creativity and providing child-centered activity. Some of teachers' responses are;

"I just felt I cannot do anything better and even to implement teaching activities that are creative and enjoyable. Having too many children in my classroom is very stressful and most of the time is to monitor the children behavior and to keep yhe classroom in control. So I think I better keep to a formal method otherwise the children do not get anything from my teaching."

(c) The pressure of expectations from Primary one Teachers and Parents.

All of the teachers cited the pressure of expectations from primary one teachers and parents which push them to concentrate more on preparing the children with the three basic skills (reading, writing and counting) rather than promoting children's creative development. One teacher explained in detail how the preschool children's achievements at the end of the year are judged by their ability to master the three basic skills by the primary one teacher.

Two teachers feel threatened by the attitudes of some of the parents they encounter. They feel under pressure to 'teach to please parents'. Parents expecting their children to be able to count and read in short period of time forced the teachers to teach three basic skills and implement teaching in formal manner and at the same time ignore other areas of learning which include creative development. Two teachers describe:

"They think that we should emphasise on the 3M's. If the children are having problems with the 3Ms, we are the one to be blame and considered our teaching is not very effective."

\section{(d) Lack of resources}

A lack of resources in terms or art and play materials are another constrain on the teachers' efforts to implement creative activities for the preschool children. Two teachers who really believe the use of materials is very important in order to promote children's creativity. All teachers stated that the budget allocated by the school is not enough and mentioned that they have spent a considerable amount of money to purchase some of the materials. Although they have a workshops to train preschool teachers to recycle unused materials as their teaching aids, they still need additional materials to make the teaching aids more attractive. Two teachers described their situation:

"I have to plan my teachings according to the resources available. Sometimes I have to change my actual planning if the resources are not enough for all children."

"I have to prepare everythings, even basic equipment like papers and others too such as water colour, crayon. It is very stressful where at the end you have to prepare everything." 


\section{Conclusion}

It is reasonable to say that creative development is indeed valuable for our education system and that a wealth of benefits for the children can be gained if it is implemented effectively. Teachers are in position to either enhance or inhibit children's creative development, thus they should make an effort to promote creativity in the classroom. Others relevant authorities such as the Ministry of Educations, the Curriculum department and teacher training institutions also play an important role in ensuring that aim of promoting children's creativity can come true. The development of children's creativity needs to be put on the forefront of the agenda so that a more holistic and meaningful development of our children is achieved.

\section{References}

Bryant, D.M., Burchinal, M., Lau, L.B. \& Sparling, J.J. (1994). Family and Classroom Correlates of Head Start Children's Developmental Outcomes. Early Childhood Research Quarterly, 9, 289-309.

Burchinal, M.R., Peisner-Feinberg, E., Bryant, D.M. \& Clifford, R. (2000). Children's Social and Cognitive Development and Child-Care Quality: Testing for Differential Associations Related to Poverty, Gender, or Ethnicity. Applied Developmental Science, 4(3), 149-165.

Burn, R. B. (1997) Introduction of research methods, (3rd Ed.). Longman.

Butcher, J.L. \& Niec, L.N. (2005). Disruptive Behaviors and Creativity in Childhood: The Importance of Affect Regulation. Creativity Research Journal, 172(2), 181-193.

Cassidy, D.I., Buell, M.I., Pugh-Hoese, S., \& Russell, S. (1995). The effect of education on child care teachers' beliefs and classroom quality: year one evaluation of the TEACH early childhood associate degree scholarship program. Early Childhood Research Quarterly, 10(2), 171-183.

Chang, L. (2003). Variable Effects of Children's Aggression, Social Withdrawal, and Prosocial Leadership as Functions of Teacher Beliefs and Behaviors. Child Development, 74(2), 535-548.

Cooney, T.J. and F.L. Lin, 2001. Making Sense of Mathematics Teacher Education. 1st Edn., Kluwer Academic Publ., Dordrecht, pp:335.

Diakidoy, L. A. \& Kanari, E. (1991). Students Teachers' Beliefs about creativity. In British Educaional Research Journal, Apr 99, 25(2), pp.225.

Grouws, D. A (2006). Handbook of Research on Mathematics Teaching and Learning. 1st Edn., National Council of Teachers of Mathematics, Reston, ISBN-10: 9781593115982, pp: 784.

Hofer, B. K. \& Pintrich, P. R. (1997). The development of epistemological theories: Beliefs about knowledge and knowing and their relation to learning. Review of Educational Research, 67(1), 88-140.

Howard-Jones, P.A., Jones, J.R. \& Sutton, L. (2002). the Effect of Play on the Creativity of Young Children During Subsequent Activity. Early Child Development and Care, 172(4), 323-328.

Kang, N.H., \& Wallace, S.C. (2005). Secondary science teachers' use of laboratory activities: Linking epistemological beliefs, goal and practices. Science Education, 89, 140-165.

Kupari, P., 2003. Instructional practices and teachers' beliefs in finnish mathematics education. Stud. Educ. Eval., 29:243257.

Levitt, E.K. (2001). An analysis of elementary teachers' beliefs regarding the teaching and learning of science. Science education, 86, 1-22.

Luft, J.A. (1999). Teachers' salient beliefs about aproblem solving demonstration classroom in-service program. Journal of Science Teachers Education, 36(2), 141-158.

Mashburn, A.J., Pianta, R.C., et al (2008). Measures of Classroom Quality in Prekindergarten and Children's Development of Academic, Language, and Social Skills. Child Development, 79(3), 732-749.

Mindham, C. (2005). Creativity and the young child. Early Years, 25(1), 81-84.

Ministry of Education Malaysia, (2001). Huraian Sukatan Pelajaran : Pendidikan Muzik. Kuala Lumpur. 
Ministry of Education, (2009). Kuala Lumpur.

Pajares, M.F., (1992). Teachers' beliefs and education research: Cleaning up a messy construct. Review of Education Research, 62, 307-332.

Peisner-Feinberg, E.S., Burchinal, M.R., et al (2001). The Relation of Preschool Child-Care Quality to Children's Cognitive and Social Development Trajectories through Second Grade. Child Development, 72(5), 1537-1553.

Pianta, R., Howes, C. et al (2005). Features of Pre-Kindergarten Programs, Classrooms, and Teachers: Do They Predict Observed Classroom Quality and Child-Teacher Interactions? Applied Developmental Science, 9(3), 144-159.

Pianta, R., Howes, C. et al (2005). Features of Pre-Kindergarten Programs, Classrooms, and Teachers: Do They Predict Observed Classroom Quality and Child-Teacher Interactions? Applied Developmental Science, 9(3), 144-159.

Ruggiero, V. R. (2004). The art of thinking: A guide to critical and creative thought. (7th ed.). New York: Longman.

Saracho, O.N. \& Spodek, B. (2007). Early childhood teachers' preparation and the quality of program outcomes. Early Child Development and Care, 177(1), 71-91.

Sherman, R. R \& Web, R. B (1988) "Qualitative research in education: A focus", in R. R Sherman and R. B. Web (eds) Qualitative research in education: Focus and methods. Bristol, Pa: Falmer Press, 1988.

Smith, P. (1959). Creativity: An examination of the creative process. New York: Hastings House.

Stipek, D.J., K.B. Givvin, J.M. Salmon and V.L. MacGyvers, 2001. Teachers' beliefs and practices related to mathematics instruction. Teach. Teac. Educ., 17: 213-226.

Tsai, C. (2002). Nested epistemologies: Science teachers' belief of teaching, learning and science. International Journal of Science Education, 24(8), 771-783 